\title{
FUTURE POWERTRAIN
}

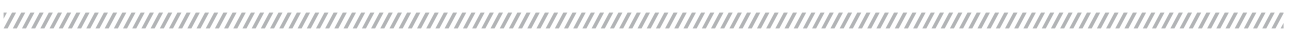

\section{Dear Reader,}

The automotive industry in general is faced with multiple pressures; the most critical of them being the need to meet the ever tightening emission regulations and stricter fuel efficiency targets. Such pressures lead to the development and implementation of new technologies in vehicles, primarily in the powertrain area. Optimising the IC engine and transmission, or looking at different hybrid and electrification options, are priority areas for manufacturers globally.

Many believe that most powertrains will have some degree of electrification inbuilt by 2025 . That would be the prime driver in meeting future fuel efficiency targets, they say. In the commercial vehicle domain, a few manufacturers are looking at bio-based ethanol to meet future challenges, while many others believe a diesel-hybrid is the best solution for the near- to long-term future.

Then, there is phenomenal amount of work being carried out on conventional powertrains as well. The gasoline direct-injection (GDI) and gasoline turbocharged direct injection (GTDI) are two very exciting developments. Conventional powertrains are being economically reinvented as $48 \mathrm{~V}$ mild hybrids, with engines downsized up to $70 \%$, reports IDTechEx.

To understand the consumer preference for future powertrain options, Morpace conducted a survey recently. The conventional petrol engine remains the consumers' first choice, followed closely by hybrids and GTDI engines. These were followed by clean diesel, plug-in hybrids, battery electric vehicles, CNG and fuel cell vehicles. There is belief that older port fuel-injection will be gradually replaced with GDI and GTDI engines. Micro and mild hybrids of the day will pave the way for stronger hybrids to come in.

Several experts we spoke to believe the current challenges and future demands would lead to newer powertrain variants in the long-term. For small vehicles, a PFI-CVT powertrain is expected to be an attractive solution, and we may see more GTDI engines launched with manual transmissions. Dual clutch transmissions (DCTs) could become more common with downsized engines, while larger vehicles such as buses and trucks could use automatic transmissions with higher number of gears.

Automated manual transmissions, for instance, are now a popular choice for many Indians. That may lead to more people opting for automatic transmissions in the future. In the future, there may not emerge an optimum powertrain, but only application-specific solutions.
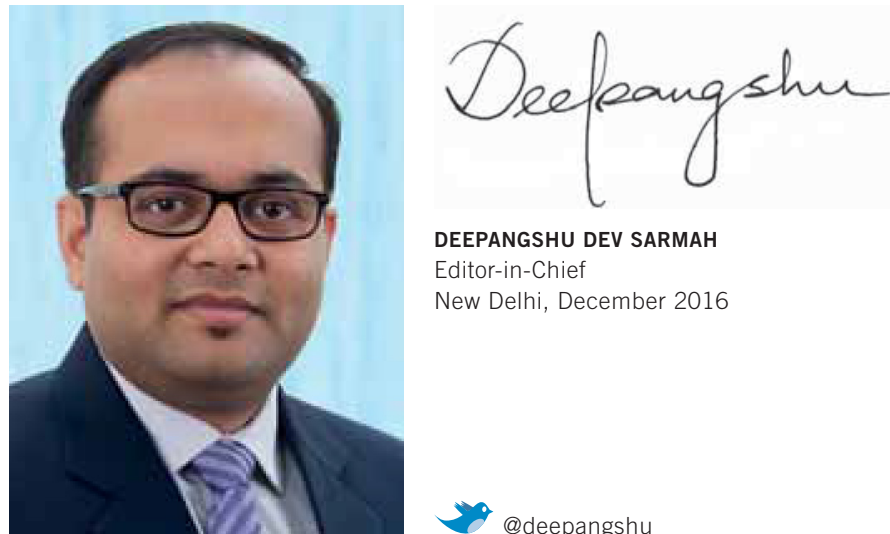

DEEPANGSHU DEV SARMAH

Editor-in-Chief

New Delhi, December 2016 